\title{
Assessment of Unconventional Oil and Gas Resources in the Jurassic Sargelu Formation of Iraq, 2014
}

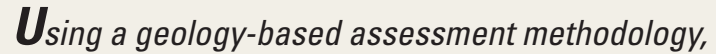 the U.S. Geological Survey estimated means of 1.6 billion barrels of unconventional oil and 0.96 trillion cubic feet of associated gas in the Jurassic Sargelu Formation of Iraq.}

\section{Introduction}

The U.S. Geological Survey (USGS) quantitatively assessed the potential for unconventional (continuous) oil and gas resources within the Jurassic Sargelu Formation of Iraq (Sargelu Continuous Oil Assessment Unit; fig. 1). Organic-rich shales of the Jurassic Sargelu Formation are one of the main petroleum source rocks for conventional fields in the Arabian Peninsula (fig. 2) (Bordenave and Hegre, 2010). The Sargelu Formation consists of marine shales, with as much as 10 weight percent sulfur-rich Type IIS organic matter, deposited in a relatively deep, anoxic Jurassic depocenter. The potential for volumes of oil retained in the Sargelu Formation source-reservoir rock system following oil migration, cracking, or degradation is the focus of this assessment. Conventional oil and gas resources of Iraq were assessed by the USGS in 2012 (U.S. Geological Survey World Energy Assessment Team, 2012).

The USGS assessment methodology consists of a well-performance approach (Charpentier and Cook, 2011) that recognizes the geologic variability within assessed reservoirs. For non-U.S. assessments, the USGS assesses shale-gas or shale-oil reservoirs that (1) contain greater than 2 weight percent total organic carbon (TOC), (2) are within the proper thermal maturity window for oil or gas generation, (3) have greater than 15-m thickness

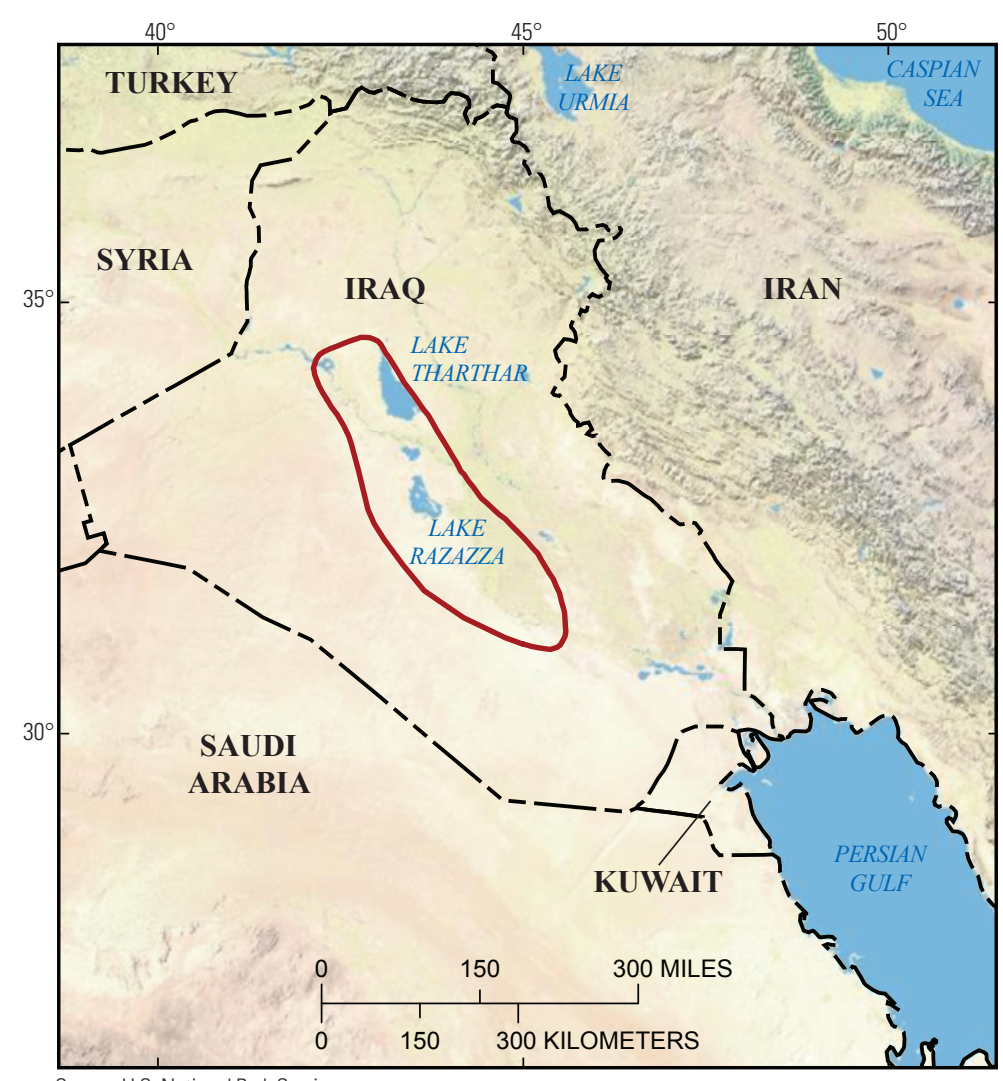

Source: U.S. National Park Service
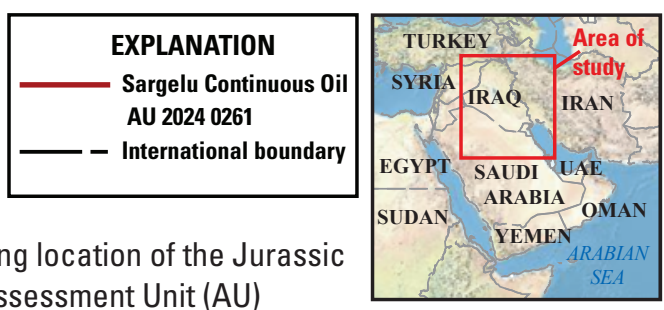

Figure 1. Map showing location of the Jurassic Sargelu Formation Assessment Unit (AU) assessed in this study.

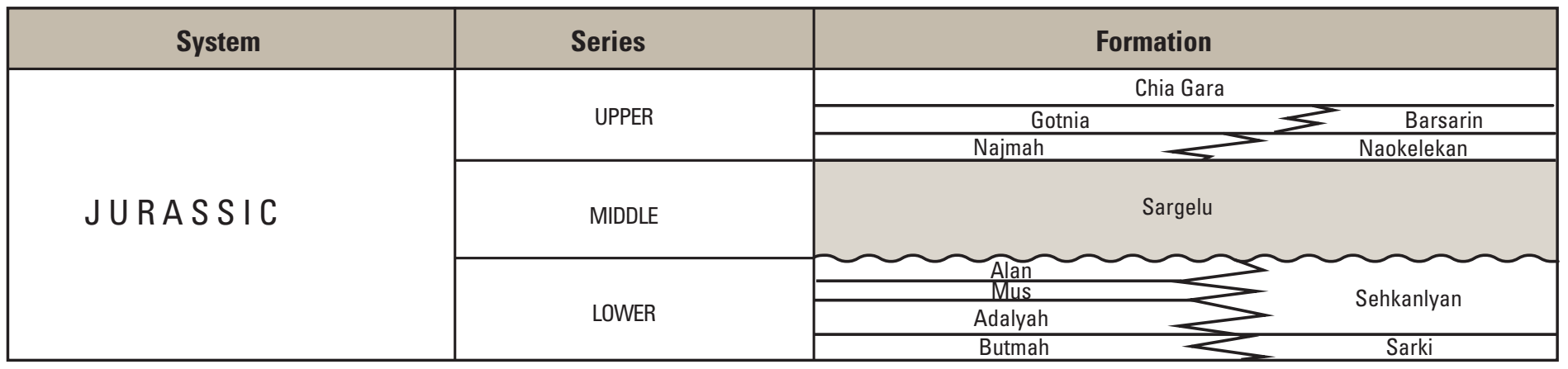

Figure 2. Jurassic stratigraphy within the study area of Iraq. 
of organic-rich shale, and (4) contain Type I or II organic matter. These specific USGS criteria when applied to any given shale-oil or shale-gas reservoir might significantly reduce the potential resource assessment area compared to maps made with greater than 1 weight percent TOC.

\section{Geologic Model for Assessment}

The geologic model for the assessment is summarized as follows. Volumes of oil and gas generated from organicrich, deep-basin anoxic facies of the Jurassic Sargelu Formation in the Late Cretaceous remained in the source rock, migrated long distances, or re-migrated during the late Tertiary Zagros tectonic event, which is based on known Sargelu-sourced oil occurring in some Zagros-age structures. About 30 percent of the assessment unit (AU) area at the mode is estimated to contain adequate source facies that were relatively unaffected by structural movements and might have retained oil in the source-reservoir system. Upper Jurassic Gotnia Formation evaporites that overlie the Sargelu Formation likely provide a partial seal to the sourcereservoir system. Shales of the Naokelekan Formation were not included in this assessment, as the Naokelekan potentially is a separate source-reservoir rock system.

The input data for the Jurassic Sargelu Continuous Oil AU are shown in table 1.

\section{Resource Summary}

The USGS quantitatively assessed unconventional oil and gas resources in the Jurassic Sargelu Formation of Iraq (table 2). For unconventional oil resources, the mean total is 1,606 million barrels of oil (MMBO), with a range from 327 to 3,730 MMBO; for associated gas the mean total is 963 billion cubic feet (BCFG), with a range from 183 to 2,315 $\mathrm{BCFG}$; and a mean total of 29 million barrels of natural gas liquids (MMBNGL), with a range from 5 to $72 \mathrm{MMBNGL}$. These resource estimates are for undiscovered, technically recoverable volumes of oil and gas and do not reflect volumes of economically recoverable resources.

Table 1. Key assessment input data for the unconventional assessment unit in the Jurassic Sargelu Formation, Iraq.

[EUR (estimated ultimate recovery per well), well drainage area, and success ratios are from U.S. shale-gas and shale-oil analogs. MMBO, million barrels of oil; BCFG, billion cubic feet of gas; AU, assessment unit; \%, percent. The average EUR input is the minimum, median, maximum, and calculated mean]

\begin{tabular}{|l|c|r|r|r|}
\hline \multirow{2}{*}{ Assessment input data } & \multicolumn{4}{|c|}{ Sargelu Continuous 0il AU } \\
\cline { 2 - 5 } & Minimum & Mode & Maximum & $\begin{array}{c}\text { Calculated } \\
\text { mean }\end{array}$ \\
\hline Potential production area of AU (acres) & 13,037 & $3,911,100$ & $13,037,000$ & $5,653,712$ \\
\hline Average drainage area of wells (acres) & 80 & 160 & 220 & 153 \\
\hline Success ratios (\%) & 10 & 50 & 90 & 50 \\
\hline Average EUR (MMB0, oil; BCFG, gas) & 0.04 & 0.08 & 0.2 & 0.086 \\
\hline
\end{tabular}

Table 2. Jurassic Sargelu Formation assessment results.

[MMBO, million barrels of oil; BCFG, billion cubic feet of gas; MMBNGL, million barrels of natural gas liquids; TPS, total petroleum system; AU, assessment unit. Results shown are fully risked estimates. For gas accumulations, all liquids are included under the NGL (natural gas liquids) category. F95 represents a 95-percent chance of at least the amount tabulated. Other fractiles are defined similarly. Fractiles are additive under assumption of perfect positive correlation]

\begin{tabular}{|c|c|c|c|c|c|c|c|c|c|c|c|c|c|c|}
\hline \multirow{3}{*}{$\begin{array}{l}\text { Total Petroleum System } \\
\text { (TPS) } \\
\text { and Assessment Units (AUs) }\end{array}$} & \multirow{3}{*}{$\begin{array}{c}\text { AU } \\
\text { Probability }\end{array}$} & \multirow{3}{*}{$\begin{array}{c}\text { Accumulation } \\
\text { Type }\end{array}$} & \multicolumn{12}{|c|}{ Total Undiscovered Resources } \\
\hline & & & \multicolumn{4}{|c|}{ Oil (MMBO) } & \multicolumn{4}{|c|}{ Gas (BCFG) } & \multicolumn{4}{|c|}{ NGL (MMBNGL) } \\
\hline & & & F95 & $\mathrm{F50}$ & $\mathrm{F5}$ & Mean & F95 & $\mathrm{F50}$ & $\mathrm{F5}$ & Mean & F95 & $\mathrm{F50}$ & $\mathrm{F5}$ & Mean \\
\hline \multicolumn{15}{|l|}{ Sargelu TPS } \\
\hline $\begin{array}{l}\text { Sargelu Continuous Oil } \\
\text { AU (20240261) }\end{array}$ & 1.0 & Oil & 327 & 1,357 & 3,730 & 1,606 & 183 & 793 & 2,315 & 963 & 5 & 23 & 72 & 29 \\
\hline $\begin{array}{l}\text { Total unconventional } \\
\text { resources }\end{array}$ & & & 327 & 1,357 & 3,730 & 1,606 & 183 & 793 & 2,315 & 963 & 5 & 23 & 72 & 29 \\
\hline
\end{tabular}

\section{References Cited}

Bordenave, M.L., and Hegre, J.A., 2010, Current distribution of oil and gas fields in the Zagros fold belt of Iran and contiguous offshore as the result of the petroleum systems, in Leturmy, P., and Robin, C., eds., Tectonic and stratigraphic evolution of Zagros and Makran during the Mesozoic-Cenozoic: Geological Society, London, Special Publications, v. 330, p. 291-353.

Charpentier, R.R., and Cook, T.A., 2011, USGS methodology for assessing continuous petroleum resources: U.S. Geological Survey Open-File Report 2011-1167, 75 p.

U.S. Geological Survey World Energy Assessment Team, 2012, Assessment of undiscovered conventional oil and gas resources of the Arabian Peninsula and Zagros fold belt, 2012: U.S. Geological Survey Fact Sheet 2012-3115, 4 p.

\section{Sargelu Assessment Team:}

Christopher J. Schenk, Janet K. Pitman, Ronald R. Charpentier, Timothy R. Klett, Stephanie B. Gaswirth, Michael E. Brownfield, Heidi M. Leathers, Tracey J. Mercier, and Marilyn E. Tennyson.

\section{For Further Information:}

Assessment results are available at the USGS Energy Resources Program Web site, http://energy.usgs.gov/oilgas/.

Publishing support provided by the U.S. Geological Survey

Denver and Tacoma Publishing Service Centers 